JIEB (ISSN : 2442-4560) available online at : ejournal.stiepancasetia.ac.id

\title{
ANALISIS KINERJA KEUANGAN PADA DINAS BINA MARGA DAN SUMBER DAYA AIR KABUPATEN BANJAR
}

\author{
Fariz Syahidi \\ Dinas Bina Marga Dan Sumber Daya Air Kabupaten Banjar \\ Jl. Pangeran Hidayatullah No. 5, Martapura, Kab. Banjar, Kalimantan Selatan \\ e-mail: farizsyahidi@gmail.com
}

\begin{abstract}
The purpose of this study was to determine the effectiveness, efficiency and growth on Highways and Water Resources Office of Banjar regency. The data analysis method was descriptive quantitative. The results showed that the average performance of the financial management of the efficiency ratio in 2013, 2014, 2015 was not efficient, due to the lack of savings in indirect expenditures or the payment of salaries of civil servants. Meanwhile, the effectiveness ratio in 2014 and 2015 were effective but in 2013 was quite effective. The effectiveness achievement was based on employees' performance to realize performance targets and financial targets. The growth of revenue, capital expenditure and operational expenditure showed high to very high results. It means that the development growth increased every year, especially in capital spending as a means to financed infrastructure development for roads, bridges and maintenance.
\end{abstract}

Keywords: efficiency, effectiveness, growth

\begin{abstract}
Abstrak: Tujuan penelitian ini adalah untuk mengetahui nilai efektifitas, efisiensi dan pertumbuhan pada Dinas Bina Marga dan Sumber Daya Air Kabupaten Banjar. Metode analisis data dalam penelitian ini adalah kuantitatif deskriptif. Hasil penelitian menunjukkan bahwa rata-rata kinerja pengelolaan keuangan pada rasio efisiensi tahun 2013, 2014 dan 2015 tidak efisien. Hal ini dikarenakan tidak adanya penghematan pada belanja tidak langsung atau pembayaran gaji PNS. Pada rasio efektifitas tahun 2014 dan 2015 efektivitas dan tahun 2013 cukup efektivitas. Pencapaian hasil efektifitas didasarkan pada hasil kinerja pegawai yang mampu merealisasikan target kinerja dan target keuangan. Pertumbuhan PAD, belanja modal dan belanja operasional menunjukan hasil yang tinggi hingga sangat tinggi. Hal ini berarti dari tahun ke tahun pertumbuhan pembangunan mengalami peningkatan terutama pada belanja modal sebagai sarana untuk pembiayaan pembangunan infrastruktur pembangunan jalan, jembatan dan pemeliharaannya.
\end{abstract}

Keywords: efisiensi, efektifitas, pertumbuhan

\section{Latar Belakang}

Sistem akuntansi keuangan dalam sebuah instansi pemerintah merupakan suatu hal yang penting untuk diperhatikan karena sistem akuntansi keuangan dapat digunakan sebagai alat pengatur dan pengendalian untuk seluruh kegiatan keuangan. Penerapan sistem berdasarkan peraturan yang ditetapkan bertujuan untuk mengatur dan melindungi kekayaan atau aset milik instansi yang bersangkutan. Dengan diterapkan sistem yang baku, diharapkan semua aktivitas instansi pemerintah dapat dijalankan dengan efisien sesuai kebijakan yang telah diterapkan oleh pemerintah.

Dinas Bina Marga dan Sumber Daya Air merupakan salah satu instansi yang berada di bawah pemerintah kabupaten Banjar yang bertugas untuk memberikan pelayanan dalam hal penyediaan fasilitas-fasilitas umum yang dibutuhkan oleh masyarakat dan pemerintah, yang tentunya memiliki peranan penting terhadap peningkatan kesejahteraan masyarakat yang ada di kabupaten Banjar. 
Adapun tujuan dari penelitian ini adalah untuk mengetahui nilai efektifitas, efisiensi dan pertumbuhan untuk periode tahun 2013, 2014 dan 2015 pada Dinas Bina Marga dan Sumber Daya Air Kabupaten Banjar.

\section{Kajian Literatur}

Menurut Akbar (2010:23) keuangan daerah adalah semua hak dan kewajiban daerah dalam rangka penyelenggaraan pemerintah daerah yang dapat dinilai dengan uang, termasuk, di dalamnya segala bentuk kekayaan yang berhubungan dengan hak dan kewajiban daerah, dalam kerangka anggaran dan pendapaatan dan belanja dearah.

Menurut Mahsun (2011:81) anggaran pendapatan dan belanja daerah (APBD) adalah daftar yang memuat rincian penerimaan daerah dan pengeluaran/belanja daerah selama satu tahun. APBD ditetapkan dengan peraturan daerah untuk masa satu tahun, mulai dari 1 Januari sampai dengan tanggal 31 Desember.

Menurut Harahap (2011) rasio keuangan adalah angka yang diperoleh dari hasil perbandingan dari suatu pos laporan keuangan dengan pos lainnya yang mempunyai hubungan yang relevan dan signifikan. Alat rasio keuangan yang digunakan adalah analisis rasio yang dikembangkan berdasarkan data keuangan yang bersumber dari anggaran pendapatan belanja daerah (Halim, 2012:128) yaitu sebagai berikut ini.

1. Rasio kemandirian keuangan daerah, menunjukkan kemampuan pemerintah daerah dalam membiayai sendiri kegiatan pemerintah, pembangunan dan sesuai target yang ditetapkan, pelayanan kepada masyarakat yang telah membayar pajak dan retribusi sebagai sumber pendapatan yang diperlukan daerah.

2. Rasio efektivitas keuangan daerah menggambarkan kemampuan pemerintah daerah dalam merealisasikan pendapatan asli daerah yang direncanakan dibandingkan dengan target yang ditetapkan berdasarkan potensi riil daerah.

3. Rasio efisiensi keuangan daerah rasio efisiensi adalah rasio yang menggambarkan perbandingan antara besarnya biaya yang dikeluarkan untuk memperoleh pendapat- an dengan realisasi pendapatan yang diterima.

4. Rasio pertumbuhan untuk mengukur seberapa besar kemampuan pemerintah daerah/pemerintah kota dalam mempertahankan dan meningkatkan keberhasilannya yang telah dicapai dari satu periode ke periode berikutnya dengan mengetahui pertumbuhan untuk masing-masing komponen penerimaan (PAD dan total pendapatan) dan pengeluaran (belanja pembangunan).

Analisis rasio keuangan APBD dilakukan dengan membandingkan hasil yang dicapai dari satu periode dibandingkan dengan periode sebelumnya sehingga dapat diketahui bagaimana kecenderungan yang terjadi. Dengan analisis ini pemerintah dapat menilai kemandirian keuangan daerah dalam membiayai penyelenggaraan otonomi daerah, mengukur efektifitas dan efisiensi dalam merealisasikan pendapatan daerah, mengukur sejauh mana aktivitas pemerintah dalam membelanjakan pendapatan daerahnya, mengukur kontribusi masing-masing sumber pendapatan dalam pembentukan pendapatan daerah, dan dapat mengukur layak/tidak layak pemerintah daerah dalam mengembalikan angsuran pokok pinjaman.

\section{Metode Penelitian}

Jenis data yang digunakan dalam penelitian ini terdiri dari :data kualitatif dan data kuantitatif. Sumber data yang digunakan pada penelitian ini adalah data primer dan data sekunder. Data primer berupa data kuantitatif dalam bentuk angka antara lain data laporan realisasi anggaran belanja Dinas Bina Marga dan Sumber Daya Air Kabupaten Banjar, dan struktur organisasi. Data sekunder berupa informasi lisan maupun tertulis dari pimpinan dan staf. Data sekunder juga diperoleh dari perpustakaan, internet, buku-buku teks mengenai manajemen pemasaran, artikel-artikel dari website dan beberapa literatur yang relevan.

Teknik pengumpulan data dilakukan dengan wawancara, observasi dan dokumentasi. Teknik analisis data menggunakan metode analisis deskriptif kuantitatif. Selanjutnya, peneliti melakukan pengukuran ke- 
mandirian, pengukuran efisiensi, pengukuran efektivitas dan pengukuran pertumbuhan pembangunan. Kemudian, peneliti membuat gambar tabulasi atas tingkat efektivitas tahun 2012-2015 guna melihat kenaikan atau penurunan yang terjadi pada Dinas Bina Marga dan Sumber Daya Air Kabupaten Banjar. Selanjutnya, ditarik kesimpulan berdasarkan persentase selisih dan capaian pendapatan. Jika rencana anggaran lebih besar daripada realisasi maka artinya tidak menguntungkan. Pendapatan juga dapat dikatakan tidak menguntungkan apabila persentase selisihnya menunjukkan selisih kurang. Sebaliknya, jika rencana anggarannya lebih kecil daripada realisasi dan persentase selisihnya menunjukkan selisih lebih maka artinya menguntungkan.

\section{Hasil Penelitian dan Pembahasan}

Laporan keuangan ini menjadi bahan sarana informasi bagi para analis dalam pengambilan keputusan serta dapat menggambarkan posisi keuangan, hasil yang telah dicapai, dan arus dana (kas) dalam satu periode tertentu oleh organisasi. Laporan keuangan merupakan media yang sangat penting, karena ia dapat memberi informasi yang dibutuhkan para stakeholder dalam membuat berbagai keputusan dan kebijakan organiasi. Jenis laporan keuangan antara lain laporan realisasi anggaran dan laporan neraca.

Realisasi pendapatan daerah tahun 2013 sebesar Rp 585.665.758 dengan target sebesar Rp 722.305.500 atau selisih sebesar Rp 136.639.742. Sementara itu, realisasi belanja daerah sebesar Rp 18.394.332.434 dari target sebesar Rp 158.306.458.348 atau selisih sebesar Rp 39.912.125.914.

Pada tahun 2014, realisasi pendapatan daerah sebesar Rp 565.743.956 dengan target sebesar Rp 722.305.500 atau selisih sebesar Rp 156.561.544. Hal ini menunjukan adanya kenaikan pendapatan dari tahun sebelumnya. Sementara itu, realisasi belanja daerah sebesar Rp 129.388.848.002 dari target sebesar Rp 137.490.412.634 atau selisih sebesar Rp 8.101.564.632. Dari segi realisasi, terjadi kenaikan dari tahun sebelumnya.

Pada tahun 2015 realisasi pendapatan daerah sebesar Rp 652.474.188 dengan target sebesar Rp 722.305.500 atau selisih sebesar
Rp 69.831.312. Hal ini menunjukan adanya kenaikan pendapatan dari dua tahun sebelumnya. Sementar itu, realisasi belanja daerah sebesar Rp 135.370.798.105 dari target sebesar $\mathrm{Rp}$ 152.047.607.041 atau selisih sebesar $\mathrm{Rp}$ 16.676.808.936. Dari segi capaian target memang sisa anggaran cukup besar namun dari segi realisasi mengalami kenaikan dari dua tahun sebelumnya.

Berdasarkan neraca tahun 2013, nilai aset sebesar Rp 637.261.543.681,40, kewajiban Rp. 0 dan ekuitas dana sebesar Rp 637.261.543.681,40. Berdasarkan neraca tahun 2014, nilai aset sebesar Rp 848.205.888.917,03, kewajiban Rp 0 dan ekuitas dana sebesar Rp 848.205.888.917,03. Dari segi aset dan ekuitas dana mengalami kenaikan dari tahun sebelumnya. Berdasarkan neraca tahun 2015, nilai aset sebesar Rp 628.752.282.140,64, kewajiban $\mathrm{Rp} 0$ dan ekuitas dana sebesar Rp 628.752.282.140,00. Dari segi aset dan ekuitas dana mengalami penurunan dari dua tahun sebelumnya.

Dari hasil perhitungan rasio efektifitas, dapat dilihat bahwa efektifitas pengelolaan keuangan Dinas Bina Marga dan Sumber Daya Air Kabupaten Banjar pada tahun 2013 sebesar 121\%, pada tahun 2014 sebesar 107\% dan pada tahun 2015 sebesar 163\%. Diharapkan ada penghematan terhadap pengeluaran gaji PNS, kecuali adanya pengurangan jumlah pegawai baik karena kepindahan tempat kerja atau PNS yang memasuki masa. Hal inilah yang membedakan antara pegawai yang berstatus PNS dengan pegawai yang bekerja di swasta di mana penghematan dapat dilakukan dengan melakukan rasionalisasi.

Rasio efisiensi pada Dinas Bina Marga dan Sumber Daya Air Kabupaten Banjar pada tahun 2013 sebesar 75\%, pada tahun 2014 sebesar 94\% dan pada tahun 2015 sebesar $90 \%$. Diharapkan dengan tingginya nilai efektifitas tersebut dapat memberikan hasil yang baik bagi pembangunan di Kabupaten Banjar, yang tentunya berdampak langsung terhadap masyarakat dan mampu meningkatkan kesejateraan mereka.

Rasio pertumbuhan pada rasio pendapatan daerahpada tahun 2014 sebesar 104\% dan pada tahun 2015 sebesar 87\%. Kemudian, rasio pertumbuhan belanja modal pada ta- 
hun 2014 sebesar 76\%, dan pada tahun 2015 sebesar 93\%. Rasio pertumbuhan belanja operasional pada tahun 2014 sebesar 92\%, dan pada tahun 2015 sebesar $96 \%$. Hasil perhitungan efisiensi, efektifitas dan pertumbuhan menunjukan nilai yang baik terutama pada rasio efektifitas dengan hasil sangat efektif dan efektif. Hal ini menunjukan bahwa pencapaian realisasi sesuai dengan target yang telah ditetapkan hal ini juga berhubungan erat dengan realisasi pelaksanaan fisik di lapangan seperti pembangunan jalan, jembatan drainase dan pemeliharaannya.

Dinas Bina Marga dan Sumber Daya Air Kabupaten Banjar diharapkan mampu melakukan pembangunan berbagai sarana umum dan infrasutruktur agar selalu memperhatikan setiap rupiah yang dibelanjakan dapat berdampak terhadap kepentingan dan kebutuhan publik dan dapat dipertanggungjawabkan kepada publik. Artinya, APBD yang digunakan oleh Dinas Bina Marga dan Sumber Daya Air Kabupaten Banjar harus mampu merefleksikan tuntutan kebutuhan pembiayaan penyelenggaraan fungsi-fungsi dan tugas-tugas sesuai tuntutan dan kebutuhan stakeholder dan dapat mencerminkan kebutuhan riil masyarakat daerah sejalan dengan kerangka kebijakan nasional dan prinsip negara kesatuan yang berarti adanya tuntutan yang kuat agar konsep value for money dari penyusunan setiap mata anggaran harus selalu menerapkan konsep $2 \mathrm{E}$ yakni efisiensi dan efektivitas serta adanya pengukuran terhadap pertumbuhan pembangunan yang telah dilaksanakan.

Hasil penelitian menunjukan bahwa Dinas Bina Marga dan Sumber Daya Air Kabupaten Banjar memiliki atau menghasilkan pendapatan atau PAD yang dari tahun ke tahun mengalami perubahan yaitu ada yang mengalami kenaikan dan ada pula yang penurunan. Penurunan terjadi pada tahun 2013 di mana realisasi pendapatan sebesar Rp 585.665.758, kemudian pada tahun 2014 turun menjadi Rp 565.743.956 dan pada tahun 2015 naik menjadi sebesar Rp 652.474.188. Hasil PAD tersebut telah disetorkan ke kas daerah kabupaten Banjar.

Sebagaimana menjadi kebijakan pemerintah daerah terhadap pengelolaan keuangan pemerintah daerah yang berlaku yang menyatakan bahwa seluruh sumber pendapatan dari pihak eksternal harus dimasukkan ke dalam APBD pemerintah kabupaten Banjar, sehingga SKPD tidak memiliki sumbersumber lain kecuali APBD tersebut.

\section{Tabel 1. Rangkuman HasilPenelitian}

\begin{tabular}{|c|c|}
\hline & Kondisi yang Diharapkan \\
\hline & Diharapkan ada \\
\hline \multirow{10}{*}{$\begin{array}{l}\text { Rasio efektifitas tahun } \\
2013 \text { sebesar } 121 \% \text {, } \\
\text { tahun } 2014 \text { sebesar } \\
107 \% \text { dan tahun } 2015 \\
\text { sebesar } 163 \% \text {. }\end{array}$} & matan terhadap pen \\
\hline & gaji PNS, kecuali adany \\
\hline & pengurangan jumlah $p$ \\
\hline & wai baik karena kepinda \\
\hline & tempat kerja atau PNS \\
\hline & \\
\hline & pegawai yang ber-status $\mathrm{F}$ \\
\hline & dengan pegawai yang \\
\hline & $\begin{array}{l}\text { di swasta di } \mathrm{m} \\
\text { penghematan dapat dilaku }\end{array}$ \\
\hline & $\begin{array}{l}\text { dengan } \\
\text { rasionalisasi. }\end{array}$ \\
\hline
\end{tabular}

Rasio efisiensi tahun Diharapkan dengan tinggi2013 sebesar 75\%, nya nilai efektifitas terse-but tahun 2014 sebesar dapat memberikan hasil yang 94\% dan tahun 2015 baik bagi pemba-ngunan di sebesar $90 \%$

Kabupaten Ban-jar, yang tentunya berdam-pak langsung terhadap masyarakat dan mampu meningkatkan kesejateraan mereka.

1. Rasio pertum- Perlunya peningkatan penbuhan penda-patan capaian realisasi sesuai dedaerah ta-hun 2014 ngan target yang telah ditesebe-sar $104 \%$ dan tapkan. Hal ini juga berhutahun 2015 se- bungan erat dengan realisa-si besar $87 \%$.

2. Rasio pertum- pangan seperti pembangun-an
buhan belanja jalan, jembatan drainase dan modal tahun 2014 pemeliharaannya.

sebesar $76 \%$, dan tahun 2015 sebesar $93 \%$.

3. Rasio pertumbuhan belanja operasional ta-hun 2014 sebe-sar $92 \%$, dan ta-hun 2015 sebe-sar $96 \%$.

Rangkuman hasil penelitian dapat dilihat pada Tabel 1. Dari hasil pengamatan dan perhitungan yang dibuat menunjukan bahwa kinerja ke-uangan pada Dinas Bina Marga dan Sumber Daya Air Kabupaten Banjar memiliki kinerja yang baik. Hal ini dapat dilihat dari capaian kinerja yang secara keseluruhan hampir men-capai $100 \%$ 
tentunya hal tersebut merupakan suatu presasi yang baik dan harus dapat dipertahankan dan tentunya harus dapat ditingkatkan lagi pada tahun yang akan datang.

Sebagaimana menjadi visi dari Dinas Bina Marga dan Sumber Daya Air Kabupaten Banjar yaitu: Tersedianya infrastruktur jalan dan sumber daya air yang andal, terpa$d u$ dan berkelanjutan untuk mendukung terwujudnya kabupaten Banjar yang sejahtera, mandiri dan islami, tentunya harus didukung dengan pengelolaan dan penatausahaan keuangan yang baik agar mampu menghasilkan kinerja keuangan yang lebih baik pada tahuntahun yang akan datang.

Upaya peningkatan kinerja keuangan harus didukung oleh semua pihak mulai dari tingkat pimpinan hingga staf pelaksana, saling sinergi dan kerja sama yang baik akan mampu meyuwudkan infrastruktur jalan dan sumber daya air yang andal, terpadu dan berkelanjutan untuk mendukung terwujudnya kabupaten Banjar yang sejahtera, mandiri dan islami.

\section{DAFTAR PUSTAKA}

Akbar Bahrullah, 2010, "Fungsi Manajemen Keuangan Daerah", Majalah Pemeriksa, Edisi No. 87, Oktober.

Harahap Sofyan Syafri, 2011, Analisis Kritis atas Laporan Keuangan, Rajawali Pres, Jakarta.

Mahsun Mohammad, 2011, Pengukuran Kinerja Sektor Publik, Edisi Pertama, BPFE, Yogyakarta.

Halim Abdul dan Kusufi Syam, 2012, Akuntansi Sektor Publik, Salemba Empat, Jakarta. 